\title{
Monitoring the quality of the work of experts when they conduct accreditation examinations of educational programs
}

\section{Monitorar a qualidade do trabalho de especialistas quando realizam exames de credenciamento de programas educacionais}

\section{Monitorear la calidad del trabajo de los expertos cuando realizan exámenes de acreditación de programas educativos}

\author{
Anna Helesh $^{1}$ (D), Olena Eremenko ${ }^{1}$ iD, Myroslav Kryshtanovych $^{1}$ (iD \\ ${ }^{1}$ Lviv Polytechnic National University, Lviv, Ukraine. \\ Corresponding author: \\ Anna Helesh \\ Email: kutsevil@ukr.net \\ How to cite: Helesh, A., Eremenko, O., \& Kryshtanovych, M. (2021). Monitoring the quality of the work of experts \\ when they conduct accreditation examinations of educational programs. Revista Tempos e Espaços em Educação, \\ 14(33), e16535. http://dx.doi.org/10.20952/revtee.v14i33.16535
}

\begin{abstract}
The purpose of the study is to monitor the quality of the work of experts when they conduct accreditation examinations of educational programs. Today, the key element of accreditation of educational programs is the assessment of the activities of higher education institutions on this program by an independent visiting expert group. The expert group is formed for the educational program and consists of three people: two authoritative scientific and pedagogical (scientific) workers who have experience in educational activities in the relevant specialty and one authoritative representative of the student body who has experience in training in this specialty (in $t$ of a graduate student, if it comes to accreditation of third-level higher education programs). The result of the study is the identification of key aspects of the features of monitoring the quality of the work of experts when they conduct accreditation examinations of educational programs.
\end{abstract}

Keywords: Accreditation examinations. Education institutions. Educational programs. Experts. Pedagogical (scientific) workers.

\section{RESUMO}

O objetivo do estudo é monitorar a qualidade do trabalho de especialistas quando realizam exames de credenciamento de programas educacionais. Hoje, o elemento-chave do credenciamento de programas educacionais é a avaliação das atividades das instituições de ensino superior neste programa por um grupo de especialistas visitantes independentes. O grupo de especialistas é formado para o programa educacional e é composto por três pessoas: dois profissionais científicos e pedagógicos (científicos) com experiência em atividades educacionais na especialidade pertinente 
e um representante autorizado do corpo discente com experiência em treinamento nesta especialidade (em t de aluno de pós-graduação, se se tratar de credenciamento de programas de ensino superior de terceiro nível). O resultado do estudo é a identificação dos principais aspectos das características de monitoramento da qualidade do trabalho dos especialistas quando realizam exames de credenciamento de programas educacionais.

Palavras-chave: Especialistas. Exames de credenciamento. Instituições de ensino superior. Programas educacionais. Trabalhadores pedagógicos (científicos).

\section{RESUMEN}

El propósito del estudio es monitorear la calidad del trabajo de los expertos cuando realizan exámenes de acreditación de programas educativos. Hoy en día, el elemento clave de la acreditación de programas educativos es la evaluación de las actividades de las instituciones de educación superior en este programa por parte de un grupo de expertos visitantes independientes. El grupo de expertos se forma para el programa educativo y consta de tres personas: dos trabajadores científicos y pedagógicos (científicos) autorizados que tienen experiencia en actividades educativas en la especialidad correspondiente y un representante autorizado del cuerpo estudiantil que tiene experiencia en la formación en esta especialidad. (en $t$ de un estudiante de posgrado, si se trata de la acreditación de programas de educación superior de tercer nivel). El resultado del estudio es la identificación de aspectos clave de las características del seguimiento de la calidad del trabajo de los expertos cuando realizan exámenes de acreditación de programas educativos.

Palabras clave: Exámenes de acreditación. Expertos. Instituciones de educación superior. Programas educativos. Trabajadores pedagógicos (científicos).

\section{INTRODUCTION}

The process of European integration and globalization requires reforming the national higher education system and bringing it in line with European standards (ESG-2015). The implementation of this strategy requires the modernization of the entire domestic system of higher education, which is directly related to the improvement of its quality.

Taking this into account, the procedure for external assessment of the quality of educational programs and educational activities for these programs in higher education institutions of Ukraine is gaining relevance, the main procedure of which is accreditation examination. In this context, there is a need for specialists who have sufficient knowledge, skills and abilities to carry out high-quality peer review in the educational sphere (Povorina, 2021;). We believe that the key elements in the implementation of high-quality peer review are knowledge of the Criteria for assessing the quality of educational programs and the ability to apply them in accreditation examinations of educational programs and educational activities of higher educational institutions in these programs. It should also be noted that the systematic training of such specialists in Ukraine has not yet been carried out (Kurgansky, 2021; Shvardak, 2021; Sydorenko, 2020; Sagitova, 2020; Mares, 2021).

Today in Ukraine accreditation examinations of educational programs are carried out by the National Agency for Quality Assurance in Higher Education (National Agency). One of the important tasks of the National Agency is the training and selection of experts, the formation of expert groups from them for the qualitative conduct of accreditation examinations and the establishment of the compliance of educational programs with the criteria for assessing the quality of educational programs, taking into account the standards and recommendations for quality assurance in the European Higher Education Area. Expert groups are formed in the composition of three people from scientific and pedagogical workers and student education applicants ()Kryshtanovych, 2021; Netreba, 2021; Dudka, 2020; Bekh, 2021; Alenina, 2021). The work of the expert groups consists of the study of information about self-assessment, materials attached to them and other materials 
related to the educational program and the activities of higher educational institutions on this program; travel to higher educational institutions in order to clarify the facts specified in the information on self-assessment and communication with representatives of interested parties about the educational program and the activities of higher education institutions under this program; formation of recommendations for improving the quality of educational activities for this program, as well as drawing up reports on the results of accreditation examinations.

\section{METHODOLOGY}

The analysis of the problem was carried out by using questionnaire. The questionnaire is designed in the form of an Internet survey using the public resource Google Forms with the condition of maintaining anonymity. Such a tool allows you to create and send invitations to participate in a survey to e-mails and social media pages of potential respondents. Automatic saving of respondents' answers made it possible to analyze and visualize the results in the form of diagrams in the MS Office environment.

\section{RESULTS AND DISCUSSION}

The survey was conducted between May and December 2020. In total, 154 respondents took part in the survey, who were directly involved in meetings with expert groups from the National University "Polytechnica" from among the following representatives: guarantors of educational programs, heads or representatives of departments in which educational programs are implemented, scientific and pedagogical workers, directly answer for the content of educational programs and / or spread on them; applicants for higher education (including graduate students) of various courses, representatives from the student government of the university (including the scientific society of students, graduate students, doctoral students, the council of young scientists), representatives of employers who are involved in the implementation of the quality assurance of educational programs and graduates of educational programs The questionnaire was sent to respondents after their meetings with expert groups and familiarization with reports on the results of accreditation examinations of educational programs.

As a result of the survey, it was found that the largest share of respondents from the total number of respondents is accounted for by representatives of academic staff (30.5\%) and applicants for higher education (including graduate students) (21.4\%). Also active participants in the study were guarantors of educational programs and managers or representatives of departments in which educational programs are implemented (14.9\%). It should be noted that representatives from among graduates of educational programs (5.2\%), from the student government (including the scientific society of students, graduate students, doctoral students, the Council of Young Scientists) (5.7\%), from among employers $(5,8 \%)$, also showed interest in the survey.

To achieve the goal of the research, respondents were asked a number of questions aimed at assessing the quality of work of experts during their accreditation examinations of educational programs at the National University "Polytechnic". In the final part of the questionnaire, respondents are asked to summarize their own suggestions and recommendations for improving the quality of work of experts during their accreditation examinations of educational programs of the Free Economic Zone.

In order to describe in more detail the quality of work of each of the experts, some questions of the questionnaire were focused on each of the members of the expert group separately, in particular on the chairman of the expert group and two members (representative of education and higher education). 
First of all, respondents were asked to assess the quality of work of experts during their accreditation examinations of educational programs in general, using a linear scale from 1 (poor) to 10 (excellent)

assessment of the quality of work of chairmen and members of expert groups from among the representatives of education (scientific and pedagogical workers) ranges from 8 to 10 points, which is as close as possible to the assessment of excellent. Respondents rated the quality of work of members of expert groups from among higher education seekers (including graduate students) with a slightly lower score - from 7 to 10 points, which is not a significant shortcoming.

So we can point out that in general, experts in the accreditation of educational programs perform their work well and have the necessary competencies - a dynamic combination of knowledge, skills and practical skills, ways of thinking, professional, ideological and civic qualities, moral and ethical values that determine the ability of the individual successfully carry out their professional activities.

The next important area of our study was the study of some professional competencies, the possession of which was demonstrated by experts during their accreditation examinations of educational programs.

Based on the materials of the researcher SL Bratchenko, who proposes to combine the professional competencies of experts in the field of education into five conditional groups, in particular: personal qualities of an expert, communicative competence, methodological and methodological literacy, expert training and practical experience, the following question was formulated.

Thus, the respondents had to note which of the proposed professional competencies were demonstrated by the experts during their accreditation examinations of educational programs (Fig. 1).

Figure 1. The results of the survey on professional competencies possessed by experts during their accreditation examinations of educational programs.

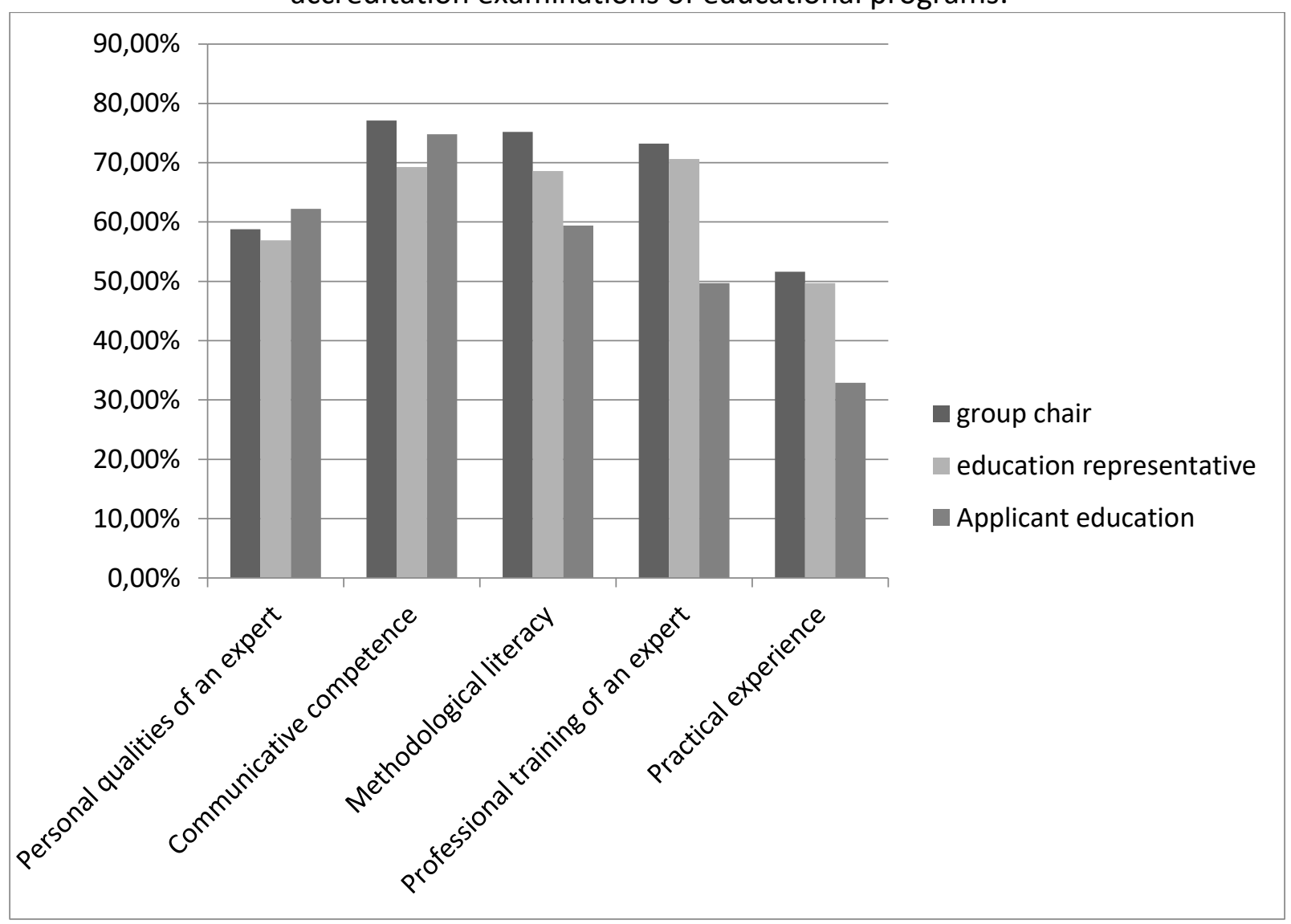


The results of the survey indicate that all members of the expert groups have professional competencies, among which communicative competence, methodological and methodological literacy and professional training of an expert prevail (over 70\%). We refer to communicative competence as the ability to establish contact, to adequately express one's position, communicative flexibility and constructiveness, readiness to solve interpersonal problems. Methodological and methodological literacy is manifested in the knowledge of the methodology of examination, the ability to select, modify and develop research methods, taking into account the specific tasks and conditions of the examination, the ability to conduct expert research. The professional training of an expert is formed during the development of the curriculum developed by the National Agency.

It will be advisable to pay attention to the personal qualities of an expert as one of the professional competencies. Thus, according to the results of the survey, it can be seen that only $58.8 \%$ of chairmen of expert groups have this competence, $56.9 \%$ - members from among representatives of education and $62.2 \%$ - from among applicants for higher education. The personal qualities of an expert include: criticality and heuristic, willingness to open and work in new situations for oneself, tolerance, the ability to decentrate, seeing the situation from different points of view, observation and sensitivity, intuition, tact, independence, adherence to principles, the ability not to succumb to pressure other people.

An equally important professional competence for experts from among applicants for higher education is the professional training of an expert. As can be seen from Fig. 1, this competence was noted by respondents only in $49.7 \%$ of applicants for higher education. Such data, in our opinion, indicate that, in addition to the availability of special education among experts - applicants for higher education, there is a need to increase their knowledge of the main modern approaches, trends and innovations in the field of higher education, psychological literacy, knowledge of basic approaches to accreditation examinations of educational programs and the practice of their use, knowledge of the legal framework and laws related to ensuring the quality of higher education in general.

The responses received suggest that the experts lack practical experience. As Bratchenko notes, an "ideal" expert must have practical experience, namely, experience in the field of education, experience in real psychological and pedagogical research, the use of humanitarian methods, experience in participating in accreditation examinations. At the same time, according to the authors, the lack of practical experience by experts is not a big problem now, because in the future they will be able to acquire it both when they conduct accreditation examinations of educational programs and as participants in this process from their own institution of higher education.

The likelihood of an objective assessment of the quality of the work of experts directly depends not only on their professional competencies, but also on the expert skills and knowledge that they possess.

Today in Ukraine there is already a separate experience in training experts on the accreditation of educational programs, which is carried out by the National Agency in accordance with the Procedure for the selection and maintenance of the register of experts of the National Agency for Quality Assurance in Higher Education for the accreditation of educational programs. The national agency has developed a program for training and testing experts for their skills and knowledge necessary for the proper conduct of accreditation examinations of educational programs of higher education institutions. This expert training program details such skills and knowledge:

- AB1: ability to analyze information about self-assessment of educational programs;

- AB2: ability to plan an accreditation visit based on the analysis of information about selfassessment of educational programs;

- AB3: the ability to identify problem points (conflict situations) that may arise during an accreditation visit to higher education institutions; 
- AB4: the ability to summarize their judgments about educational programs in the accreditation examination report and assess their compliance;

- AB5: ability to provide consultations to representatives of HEls on improving the quality of their educational program;

- KN1: knowledge of the Criteria for assessing the quality of educational programs and methods of their application for assessing educational programs;

- KN2: knowledge of the rules of ethical behavior of an expert during an accreditation visit.

The respondents were asked to mark, which with the skills and knowledge described above, the experts possessed when they conducted accreditation examinations of educational programs.

According to the survey results, it was determined that the experts learned better the ability to analyze information about self-assessment of educational programs and knowledge about methods of their application for assessing educational programs in accordance with the Criteria for assessing the quality of educational programs, which, according to the authors, is an extremely important element of accreditation examinations of educational programs of higher education. educational education. Note that the ability to plan an accreditation visit is mainly characteristic of the chairmen of expert groups - 67.6\%. This suggests that the National Agency is successful in selecting experts who can fulfill the duties of chairmen of expert groups.

In second place, the respondents attributed the ability to identify problematic moments (conflict situations) that may arise during an accreditation visit to higher education institutions. higher education. to improve the quality of their educational program. It should be noted that the indicators of members of expert groups from among applicants for higher education are lower than other experts, in particular, only $37.8 \%$ of applicants for higher education have mastered the ability to provide advice to representatives of higher education in order to improve the quality of their educational program. Such an indicator may be due to the fact that they are not sufficiently able to interpret conceptual provisions in the quality assurance system of higher education and make relevant recommendations on their basis, they generally lack understanding of the strategic features of the organization of the educational process in higher education, and its regulatory support, as well as sometimes the experience of teaching and methodological activities.

As a positive trend, one can characterize the fact that all members of the expert groups had knowledge of the rules of ethical behavior during the accreditation visit and successfully adhered to them. This is evidenced by the high results from Fig. 4: 77.0\% - chairmen of expert groups and 72.2\% and $79.7 \%$ - members of expert groups (representatives of education and applicants for higher education, respectively).

In order to supplement and clarify professional competencies, skills, knowledge and skills that the experts lacked for the proper conduct of accreditation examinations of educational programs, the respondents were offered an open-ended question, where they described their proposals and recommendations. Having summarized the options for answering this question, it should be noted that, on the whole, the impression from communication with the experts was positive. Most of the respondents indicated that there was no lack of professional competencies among the experts and they skillfully demonstrated the level of their knowledge, skills and abilities and duly conducted accreditation examinations of educational programs. At the same time, the share of respondents noted some aspects that the experts lacked, in particular:

- knowledge of the features of the educational program within the relevant specialty;

- lack of practical experience (especially for applicants for higher education);

- ability to communicate, logically formulate questions during meetings;

- self-control and ability to pay attention to significant differences in the course of surveys;

- too formalized approach;

- the ability to plan an accreditation visit, based on the analysis of information about the selfassessment of the educational program; 
- goodwill;

- patience when dealing with representatives of higher educational institutions .;

- knowledge and ability to select questions during meetings, taking into account the specifics of focus groups;

- ability to provide advice on improving the quality of the educational program;

- knowledge of the specifics of the educational process in a particular industry;

- knowledge and skills of a more detailed study of the official website of higher education institutions. in the direction of the activities of certain divisions;

- specifying questions for representatives of higher educational institutions .;

- the ability to combine theoretical and practical approaches to the implementation of the educational program.

To carry out proper accreditation examinations, it is also necessary to have social competencies, which include the ability to establish contact with people, the ability to listen and hear, the ability to work in a team, criticality, the ability to solve problems and conflicts, and the like. The introduction of social competences, aimed at the ability to work effectively in a team and understanding the value of collegial cooperation, the ability to present, critically analyze and argue from the theoretical and empirical points of view, your own position independently and targeted, the ability to perceive the feedback of colleagues and draw conclusions from this for your activities ...

Therefore, the next element under study was the ability of experts on accreditation of educational programs to work in a team

According to the results of the survey, it was revealed that the ability of experts in collegiality and teamwork when they conduct accreditation examinations of educational programs is provided in $94.1 \%$ and only in $5.9 \%$ this ability is partially developed.

The competence of self-management and observance of time management during their accreditation examinations of educational programs has a significant impact on the quality of the experts' work. Based on research, in the competence of self-management and time management we include:

- knowledge of the principles and techniques of personal self-organization;

- knowledge of personal professional development plans and methods of their implementation;

- knowledge of technologies for rational use of time;

- knowledge of techniques for optimizing the allocation of time resources.

- skills and abilities of organizing the expert's own work;

- the ability to carry out self-analysis of professional competencies, the development of volitional qualities and motivation to achieve success;

- skills and abilities of constant monitoring and critical analysis of the level of development of their professional and socio-personal competencies;

- the ability to systematically independently select the necessary measures for selfdevelopment;

- skills for effective use of time;

- the ability to draw up a program of an on-site accreditation examination and its observance.

Respondents' answers to the question "Did the expert group manage to observe the time management in accordance with the agreed program of the visit during their accreditation examination?" deserve a positive assessment.

Thus, $89.6 \%$ of the respondents noted that the experts skillfully adhered to time management in accordance with the agreed visit program during their accreditation examinations of educational programs. 
The effectiveness of any activity, including the expert group, is accompanied by organizational aspects. During their studies, experts on accreditation of educational programs by the National Agency are focused on their compliance with the following organizational aspects, such as: exclusively Ukrainian language of communication; moral and ethical standards of interaction with higher educational institutions; professional behavior during each meeting; mutual respect for each interlocutor; adherence to clear communication with universities; observance of behavioral and professional "taboos" for the expert of the National Agency.

Despite this, the respondents were asked to note certain aspects of the organizational work that the expert groups adhered to when they carried out accreditation examinations of educational programs.

According to the survey results, it was determined that basically $(88.8 \%)$ experts adhered exclusively to the Ukrainian language when communicating with various participants, professional behavior during each meeting (88.2\%) and mutual respect for each interlocutor $(90.1 \%)$.

At the same time, it is a matter of concern that the respondents rated such organizational aspects of the experts' work as lower than they would like:

- moral and ethical standards of interaction with universities - 75.0\%;

- compliance with clear communication with educational institutions - 73.0\%;

- observance of behavioral and professional "taboos" for the expert of the National Agency $-65.8 \%$.

Summarizing the answers to this question, we can conclude that, in general, experts understand the importance of observing the aspects of organizational work described above, but in some of them these skills need to be improved.

According to the current Regulation on the accreditation of educational programs for which the training of applicants for higher education is carried out, one of the final elements of the new accreditation examination of educational programs is the formation of recommendations by expert groups to improve the quality of educational programs and educational activities of higher educational institutions for these programs. As a rule, the provision of advice to higher educational institutions on methods / tools for improving the quality of educational programs occurs at the final briefing, which is provided for by the program of the experts' visit to higher education institutions. At the same time, the expert groups should come to a consolidated opinion regarding the recommendations and the availability of "best practices" and confirmations. An important aspect in this matter is reaching a consensus between the chairman and the members of the expert groups.

So, we decided to ask the respondents or expert groups adhered to the procedure for conducting accreditation examinations of educational programs and provided advice to higher educational institutions on methods / tools for improving the quality of educational programs

The data obtained from the results of the respondents' answers to this question indicate that in this direction the expert groups did not quite cope with the task, since only $76.3 \%$ provided advice on methods / tools for improving the quality of educational programs. The share of respondents $(22.9 \%)$ is inclined to believe that the expert groups did not formulate their recommendations in full.

So, according to the authors, this stage of accreditation examinations of educational programs of higher educational institutions is especially important, because the mission of the National Agency is focused not on inspection, but on consultative assessment of the quality of educational programs and the formation of a quality culture of higher education in Ukraine as a whole. At the same time, experts on accreditation of educational programs are key agents of positive changes in ensuring the quality of education in higher education institutions.

At the end of the study, the respondents were asked to describe their proposals and recommendations for improving the quality of the work of experts when they conduct accreditation examinations of educational programs of higher education institutions. 
Summarizing the answers of the respondents, we can note that there were some that positively characterized the quality of the experts' work, in particular, the respondents noted the high level of training, professionalism, friendliness and tolerance of the expert groups. Along with this, we consider it necessary to highlight a number of respondents' recommendations, which are aimed at improving the quality of the work of expert groups, among them:

- take into account the specifics of higher education institutions;

- reduce the formal approach;

- to expand the number of experts and take into account the complete coincidence with the specialty of the educational program;

- to conduct more seminars, trainings for experts in order to provide information relevant at that time;

- systematically monitor the quality of the work of experts in higher educational institutions of Ukraine and work out the results in detail;

- to increase the time of communication during meetings in order for experts to obtain more detailed information and to expand the range of issues;

- spend more time on communication with student focus groups;

- pay attention to the presence of autonomy and traditions in higher education institutions;

- to systematically improve the knowledge and skills of experts regarding the understanding of criteria and subcriteria and their application to assess the quality of educational programs;

- minimize additional meetings and optimize the list of additional documents;

- clearly structure time management in the visit program;

- to improve the flexibility of judgments and decision-making, taking into account the specifics of higher educational institutions and taking into account the consulting (auxiliary), and not the normative nature of the accreditation procedure for the educational program;

- provide really advice and recommendations for improvement, and not focus on the shortcomings and "weaknesses" of the educational program;

- requires improvement of professional behavior during each meeting and adherence to clear communication with higher educational institutions;

- more thoroughly analyze the information about the self-assessment of the educational program;

- to pay more attention to the scientific component of educational and scientific programs for the preparation of a doctor of philosophy;

- inform the higher educational institutions in advance about the materials with which the experts intend to get acquainted in the languages of the "online" format.

It is also worth noting that a number of respondents indicated that the best form for conducting accreditation examinations of educational programs is still in-person.

\section{CONCLUSION}

Thus, the study of the results of monitoring the quality of the work of experts during their accreditation examinations of educational programs at the National University "Polytechnic" showed that the overwhelming majority of expert groups had the necessary knowledge, skills and abilities and carried out high-quality expert assessment of educational programs.

At the same time, despite the generally positive assessment of the work of the expert groups, we believe that certain aspects of the professional training of experts (especially among applicants for higher education) require improvement: knowledge of the expert examination methodology, the ability to conduct expert research, the availability of practical experience in the field of education and the implementation of accreditation examinations of educational programs, as well as individual professional competencies, basic and special competencies, which will provide them 
with the opportunity to act as experts, consultants, analysts, developers on a wide range of interrelated aspects and areas of improving the quality of higher education in Ukraine.

Attention is demanded by the issue of expert groups providing advice on methods / tools for improving the quality of educational programs and educational activities of higher educational institutions in general. The results of the survey show that in this direction the expert groups did not quite cope with the task, and the share of the expert groups did not fully formulate their recommendations. So, improvement requires the knowledge and ability of experts to provide advice to representatives of higher educational institutions on improving the quality of educational programs, at the same time refraining from disclosing information about the results of the examination and the ability to summarize their judgments about educational programs in the reports of expert groups and assess their compliance with the Criteria at the final stage of accreditation examinations of educational programs.

The result of the study is the identification of key aspects of the features of monitoring the quality of the work of experts when they conduct accreditation examinations of educational programs.

Authors' Contributions: Helesh, A.: conception and design, acquisition of data, analysis and interpretation of data, drafting the article, critical review of important intellectual content; Eremenko, O.: conception and design, acquisition of data, analysis and interpretation of data, drafting the article, critical review of important intellectual content; Kryshtanovych, M.: conception and design, acquisition of data, analysis and interpretation of data, drafting the article, critical review of important intellectual content. All authors have read and approved the final version of the manuscript.

Ethics Approval: Not applicable.

Acknowledgments: Not applicable.

\section{REFERENCES}

Alenina, E. E., Bolotnikov, S. V., Borodacheva, L. V., Grankina, V. L., Redin, D. V., \& Senderov, V. L. (2021). Management tools in modern distributed social communities. Laplage in Journal, 7(Extra-C), 48-56. https://doi.org/10.24115/S2446$\underline{622020217 \text { Extra-C983 }}$

Bekh, V., Vashkevych, V., Kravchenko, A., Yaroshenko, A., Akopian, V., \& Antonenko, T. (2021). Education as a Way of Human Existence in a Postmodern Society. Postmodern Openings, 12(3), 01-14. https://doi.org/10.18662/po/12.3/324

Dudka, T., Chumak, M., Lytvynenko, N., Benera, V., \& Serhiienko, T. (2020). Educational systems of Eastern European countries as a subject of international comparative research. Revista Tempos e Espaços em Educação, 13(32), 1-15. https://doi.org/10.20952/revtee.v13i32.14068

Horbenko, H., Voskoboinikova-Huzieva, O., Novokhatko, L., \& Netreba, M. (2021). Video scribing as a new marketing tool for educational institutions. Laplage in Journal, 7(3A), 599-607. https://doi.org/10.24115/S2446-

$\underline{6220202173 A 1469}$

Kryshtanovych, M., Nevmerzhytska, O., Teletska, L., Yankovska, I., \& Shovsh , K. (2021). Professional competence of future primary school teachers in the context of the covid19 pandemic. Laplage in Journal, 7(3A), 463-469.

https://doi.org/10.24115/S2446-6220202173A1440

Kryshtanovych, M., Zyazyun, L., Vykhrushch, N., Huzii, I., \& Kalinska, O. (2021). Determining the main components of the formation of professional competence for students. Laplage in Journal, 7(3B), 1-8.

https://doi.org/10.24115/S2446-6220202173B1479

Kurgansky, S. I., Turavets, N. R., Rodin, V. F., Kistenev, V. V., \& Egorova , E. N. (2021). Education and self-education of students in the socionamic activity in the context of "new reality". Laplage in Journal, 7(Extra-A), 68-75.

https://doi.org/10.24115/S2446-622020217Extra-A779

Mares, G., Cojocariu, V.-M., \& Cîrtiţă-Buzoianu, C. (2021). Making Career Decisions in the Context of the COVID-19 Pandemic. An Analysis of Disadvantaged Student Groups. Postmodern Openings, 12(1), 328-346.

https://doi.org/10.18662/po/12.1/264 
Povorina, E. V., Vasileva, L. A., Ponyashova, A. S., Volkov, D. V., \& Kulyamina, O. S. (2021). Methodology for monitoring the quality of provided educational services in higher educational institutions. Laplage in Journal, 7(Extra-E), 190-197. https://doi.org/10.24115/S2446-622020217Extra-E1174

Sagitova, V. R., Karimova, L. K., Galiullin, M. Z., \& Kadyrov, R. R. (2020). Educational migration as a factor in the development of international relations. Laplage in Journal, 6(Extra-C), 1-6. https://doi.org/10.24115/S2446$\underline{622020206 \text { Extra-C617 }}$

Shvardak, M. (2021). Coaching Technology to Prepare Candidates for Leadership Roles in a Variety of Educational Settings. Postmodern Openings, 12(1), 201-222. https://doi.org/10.18662/po/12.1/255

Sydorenko, V., Shorobura, I., Ponomarenko, A., Dei, M., \& Dzhus, O. (2020). Application of technologies of formal and non-formal education for continuous professional development of the modern specialist. Revista Tempos e Espaços em Educação, 13(32), 1-24. https://doi.org/10.20952/revtee.v13i32.14729

Received: 31 June 2021 | Accepted: 12 September 2021 | Published: 9 November 2021

This is an Open Access article distributed under the terms of the Creative Commons Attribution License, which permits unrestricted use, distribution, and reproduction in any medium, provided the original work is properly cited. 